\title{
The effect of environmental management on environmental performance and firm performance in Taiwanese maritime firms
}

\author{
Ching-Chiao Yang \\ Department of Shipping and Transportation Management, \\ National Kaohsiung Marine University, \\ No. 142, Haijhuan Road, Kaohsiung City 811, Taiwan \\ Fax: +886-7-3647046 \\ E-mail: yangcc@mail.nkmu.edu.tw
}

\begin{abstract}
This paper aims to empirically examine the impact of environmental management on environmental performance and firm performance in Taiwanese maritime firms. Three critical environmental management dimensions were identified based on factor analysis: environmental management practices, environmental management auditing, and environmental management investment. A structural equation modelling (SEM) was performed to examine the effects of environmental management on environmental performance and firm performance. The results indicated that environmental management had significantly positive effects on environmental performance and firm performance. However, environmental performance was not found to be related to firm performance in this study.
\end{abstract}

Keywords: environmental management; environmental performance; firm performance; maritime firms; Taiwan.

Reference to this paper should be made as follows: Yang, C-C. (2012) 'The effect of environmental management on environmental performance and firm performance in Taiwanese maritime firms', Int. J. Shipping and Transport Logistics, Vol. 4, No. 4, pp.393-407.

Biographical notes: Ching-Chiao Yang is an Assistant Professor of the Department of Shipping and Transportation Management at National Kaohsiung Marine University, Taiwan. He received his $\mathrm{PhD}$ in Transportation and Communication Management Science from National Cheng Kung University, Taiwan. His research interests include environmental management, corporate social responsibility, transport logistics, port operations and management, and strategic management. His research papers have been published various academic journals, including the Transportation Journal, the International Journal of Shipping and Transport Logistics, the Transportation Research Part E: Logistics and Transportation Review, and others.

This paper is a revised and expanded version of a paper entitled 'Assessing the impact of environment management on Taiwanese maritime firms' presented at The 4th International Conference of Asian Shipping and Logistics, National Cheng Kung University, Tainan, Taiwan, 5-6 May 2011. 


\section{Introduction}

With the rise in concerns over pollution and climate change, the issue of environmental management has become increasingly important. Zervas (2006) stated that reducing carbon dioxide $\left(\mathrm{CO}_{2}\right)$ emissions is regarded as the best way to slow down or minimise the impact of climate change. Since the burning of fossil fuels is the major source of $\mathrm{CO}_{2}$ emissions, changing the way we use energy in the transport sector is of considerable importance (Zervas, 2006; Liao et al., 2010).

Taiwan is a relatively small island that is highly dependent on trades. According to a report published by the Ministry of Transportation and Communication (2010), over 99\% of the Taiwan's international trade is carried by sea, and maritime transportation thus plays a very important role in the economy. The industry as a whole also consumes a large amount of energy and releases large volumes of $\mathrm{CO}_{2}$.

According to the statistics published by the International Energy Agency (IEA, 2010), the total $\mathrm{CO}_{2}$ emissions from fuel combustion in Taiwan was 264.3 million tonnes in 2008. Of these, 34.6 million tonnes were from the transport sector, accounting for $13.1 \%$ of the total emissions. Moreover, Taiwan's $\mathrm{CO}_{2}$ emissions increased from 129 million tonnes in 1990, to 305 million tonnes in 2005, recording a rise of 2.4 times (Liao et al., 2010). Therefore, working to reduce such emissions is an important issue for all sectors of the economy, and it is regarded as one of the greatest challenges now faced by the shipping industry (Giziakis and Christodoulou, 2010).

A maritime firm can signal that it has implemented an environmental management system by successfully complying with the ISO 14001 standards. Moreover, a large number of previous studies (Porter, 1991; Claver et al., 2007; Zhu et al., 2008; López-Gamero et al., 2009; Yang et al., 2010) have concluded that environmental management is key to improving organisational competitiveness and achieving sustainable development. However, as yet there are few empirical investigations of the issue of environmental management in the context of maritime firms, and thus this paper undertakes an empirical examination of the impact of environmental management on environmental performance and firm performance in Taiwanese maritime firms.

There are five sections in this study. Section 1 introduces the motivation for and purpose of the research. Section 2 reviews the literature on environmental management, environmental performance and firm performance. A conceptual framework and research hypotheses are also provided in this section. Section 3 describes the research methodology, including the questionnaire design, sampling technique, and methods of analysis. Section 4 presents the results of analysis. The conclusions and implications are discussed in the final section.

\section{Literature review and research hypotheses}

\subsection{Environmental management}

The increasing emphasis on environmental issues has forced firms to implement environmental management programs, with such practices defined as "the part of the management system that includes the organizational structure, the responsibilities, practices, procedures, process and resources meant to achieve and maintain a specific environmental behavior that can reduce the impact caused by enterprise operations on the 
natural milieu" [Claver et al., (2007), p.162]. Many firms have thus worked to adopt appropriate environment management systems and comply with the ISO 14001 standards, which covers items such as environmental policy, planning, implementation and operation, checking and corrective actions, and management review.

Several environmental management practices have been identified for dealing with environmental issues, such as waste reduction, recycling, reproducing, reusing, and disposal (Murphy et al., 1994; Lee, 2008). Labonne (2006) and Darnall et al. (2008) suggested that good environmental practices should include a written environmental policy, external and internal environmental auditing, environmental accounting, publication of environmental reports, environmental training programs for employees, benchmarking, and environmental performance indicators. Zhu et al. (2008) pointed out that the so-called green supply chain management (GSCM) practices including internal environmental management, external GSCM, investment recovery, and eco-design, are positively related to a firm's environmental and economic performance. Liu et al. (2010) also noted that proactive environmental management practices should include ISO 14001 certification, cleaner production audit, recycling of by-products, eco-technical innovation, disclosure of environmental information, and environmental cooperation with external suppliers.

Based on a review of the literature relating to environmental management attributes, 16 attributes were selected for use in a questionnaire survey. They are presented in the analysis of findings derived from the survey in Section 4.

\subsection{Environmental performance}

Environmental performance is been defined as "an internal process and management tool designed to provide management with reliable and verifiable information on an ongoing basis to determine whether an organization's environmental performance is meeting the criteria set by the management of the organization" (Jasch, 2000). A number of indices that assess the reduction in a firm's environmental impact are used to measure environmental performance. These indices include reductions in use of water and energy, noise and air emissions, soil waste, risk of severe accidents, and landscape damage (Jasch, 2000; Wagner and Schaltegger, 2004; Zhu and Sarkis, 2004; Labonne, 2006). Based on a literature review centred on environmental performance, four items were drawn from previous studies (Wagner and Schaltegger, 2004; Zhu and Sarkis, 2004) and slightly revised to measure environmental performance in the current work. These four items are: EP1: reduction in the cost of energy consumption; EP2: reduction in use of paper; EP3: reduction in the disposal cost of solid waste; and EP4: reduction in the fine of severe environmental accidents.

\subsection{Firm performance}

Performance is the measurement and comparison of actual levels of achievement of specific objectives. It is used to measure the efficiency of resource allocation and the outcome of corporate objectives. Firm performance can be separated into financial and non-financial performance (Venkatraman and Ramanujam, 1986). The financial performance indicators include sales' growth, profit rate, return on investment, return on sales, return on equity, and earnings per share, whereas non-financial performance focuses on market share, new product introduction, product quality, marketing 
effectiveness, and technological efficiency. A composite measure of performance was recommended by Dess and Robinson (1984), and thus this study used a combination of both financial and non-financial measures to evaluate the performance of maritime firms.

Four performance indicators commonly used in previous research were used to measure non-financial performance (Kaplan and Norton, 1992; Lu et al., 2009; Mishra and Suar, 2010; Panayides and Polyviou, 2011), namely service quality, customer satisfaction, customer loyalty, and competitive position, and four were used to measure financial performance (Kaplan and Norton, 1992; Lu et al., 2009; Lun et al., 2010; Mishra and Suar, 2010; Lun and Marlow, 2011), namely profit rate, market share, sales' growth rate, and reduced operational cost.

\subsection{Research hypotheses}

A large number of previous studies on environmental management have concluded that the adoption of environmental management practices or programs by firms leads to good environmental performance and firm performance (Zhu and Sarkis, 2004; Zhu et al., 2008; López-Gamero et al., 2009; Shang et al., 2010). Porter (1991) pointed out that environmental management can lead to win-win situations in which both social welfare as well as the private benefits of the firm increase. Claver et al. (2007) conducted a case study and demonstrated the existence of a positive relationship between environmental management and firm performance. Darnall et al. (2008) noted that the adoption of environmental management systems can improve business performance in terms of profitability and growth, while Yang et al. (2010) found that environmental management programs could significantly enhance manufacturers' competitiveness. In addition, Zhang et al. (2011) concluded that the promotion of a green strategy contributed significantly to the competitive advantage of housing developers. Finally, Lee (2008) demonstrated that environmentally-friendly practices are positively related to environmental performance.

Based on these previous studies as discussed above, a conceptual model is proposed, as shown in Figure 1, and three research hypotheses are also formulated, as follows:

Figure 1 Research framework

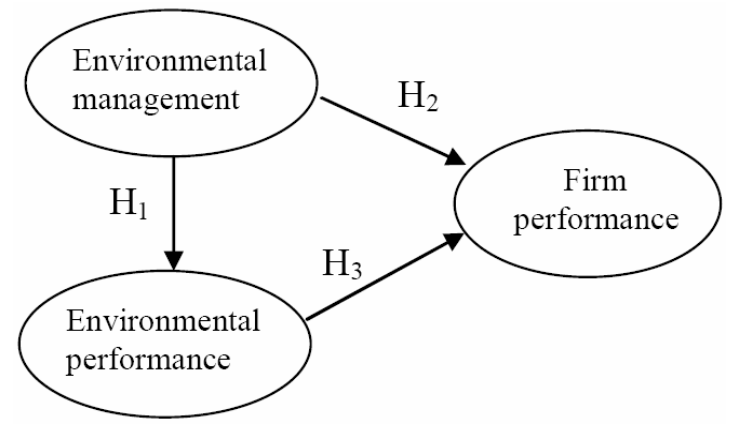

$\mathrm{H}_{1}$ Environmental management has a positive effect on environmental performance in Taiwanese maritime firms.

$\mathrm{H}_{2}$ Environmental management has a positive effect on firm performance in Taiwanese maritime firms. 
$\mathrm{H}_{3}$ Environmental performance has a positive effect on firm performance in Taiwanese maritime firms.

\section{Methodology}

\subsection{Questionnaire design and measures}

Data for this study were collected from a questionnaire survey which was designed based on the stages outlined by Churchill and Iacobucci (2002). The measures for the environmental management, environmental performance and firm performance of maritime firms used in this study were drawn from previous works, and then, to ensure their validity, they were discussed with container shipping service executives and experts. Drawing from previous studies (Labonne, 2006; Darnall et al., 2008; Lu et al., 2009), 16 environment management attributes were selected for use in the questionnaire survey and presented in the Section 4. With regard to environmental performance, a four-item scale including reduction in the cost of energy consumption, reduction in use of paper, reduction in the disposal cost of solid waste, and reduction in the fine of severe environmental accidents was adapted from Wagner and Schaltegger's (2004) and Zhu and Sarkis's (2004) works and slightly revised.

Each environmental management and environmental performance variable was assessed using a five-point Likert scale, ranging from ' $1=$ strongly disagree' to ' 5 = strongly agree'. As regards the firm performance, a five-point Likert scale, ranging from ' 1 = very poor' to ' 5 = very good' was used.

\subsection{Sampling techniques}

Typically, the Taiwanese liner shipping industry includes liner shipping companies, shipping agencies and ocean freight forwarders. The sample for this study was therefore drawn from the Directory of National Association of Chinese Ship owners and Shipping Agencies and Members of the International Ocean Freight Forwarders and Logistics Association in Taiwan. The survey questionnaire was sent to 520 managers in June 2010. The total number of usable responses was 154 . The overall response rate for this study was $29.6 \%$.

A t-test analysis recommended by Armstrong and Overton (1977) was carried out in this study to test for non-response bias. The 154 survey respondents were divided into two groups, early $(n=90,58.4 \%)$ and late $(n=64$, the remaining $41.6 \%)$, based on their response wave (first and second). T-tests were performed on the two groups' perceptions of the various environmental management attributes. The results indicated that there were no significant differences between the two groups' perceptions of the various items at the $5 \%$ significance level, and thus that non-response bias was not a problem, since the responses of late respondents appeared to reflect those of the earlier ones.

\subsection{Research methods}

An exploratory factor analysis was employed to identify the key environmental management dimensions, and a structural equation modelling (SEM) approach was subsequently used to test the research hypotheses. A two-step approach suggested by 
Anderson and Gerbing (1988) was employed to analyse the data. In the first step, confirmatory factor analysis way performed to assess the validity of the measurement model. The second step then requires estimating the structural model from the latent variables. All analyses were carried out using the SPSS 18.0 for Windows and AMOS 18.0 statistical packages.

Table 1 Respondents' profile

\begin{tabular}{|c|c|c|c|}
\hline & & $\begin{array}{l}\text { Number of } \\
\text { respondents }\end{array}$ & $\begin{array}{c}\text { Percentage of } \\
\text { respondents }\end{array}$ \\
\hline \multirow[t]{6}{*}{ Job title } & Vice president or above & 57 & 37.0 \\
\hline & Manager/assistant manager & 60 & 39.0 \\
\hline & Director/vice director & 9 & 5.8 \\
\hline & Clerk & 13 & 8.5 \\
\hline & Sales representative & 4 & 2.6 \\
\hline & Other & 11 & 7.1 \\
\hline \multirow[t]{5}{*}{ Work experience (years) } & $1-5$ & 11 & 7.1 \\
\hline & $6-10$ & 19 & 12.4 \\
\hline & $11-15$ & 31 & 20.1 \\
\hline & $16-20$ & 25 & 16.2 \\
\hline & Above 21 & 68 & 44.2 \\
\hline \multirow[t]{3}{*}{ Type of business } & Liner shipping company & 24 & 15.6 \\
\hline & Liner shipping agency & 45 & 29.2 \\
\hline & Freight forwarder & 85 & 55.2 \\
\hline \multirow[t]{3}{*}{ Ownership pattern } & Local firm & 102 & 66.2 \\
\hline & Foreign-owned firm & 30 & 19.5 \\
\hline & Foreign-local firm & 22 & 14.3 \\
\hline \multirow[t]{4}{*}{ Age of firm (years) } & $1-5$ & 4 & 2.6 \\
\hline & $6-10$ & 15 & 9.7 \\
\hline & $11-20$ & 53 & 34.4 \\
\hline & $21-30$ & 29 & 18.8 \\
\hline \multirow[t]{5}{*}{ Number of employees ${ }^{a}$} & Less than 50 & 85 & 55.6 \\
\hline & $51-100$ & 23 & 15.0 \\
\hline & $101-500$ & 26 & 17.0 \\
\hline & $501-1,000$ & 10 & 6.5 \\
\hline & Above 31 & 53 & 34.4 \\
\hline \multirow[t]{6}{*}{ Annual revenue (Million NT\$ $\left.{ }^{b}\right)^{c}$} & Less than 10 & 19 & 13.0 \\
\hline & $11-100$ & 57 & 39.0 \\
\hline & $101-1,000$ & 33 & 22.6 \\
\hline & $1,001-10,000$ & 22 & 15.1 \\
\hline & Above 1,001 & 9 & 5.9 \\
\hline & Above 10,001 & 15 & 10.3 \\
\hline
\end{tabular}

Notes: ${ }^{a}$ Represents one respondent did not provide this information

${ }^{\mathrm{b}}$ One US dollar equals approximately 32.5 New Taiwanese (NT) dollars

${ }^{c}$ Represents eight respondents did not provide this information. 


\subsection{Characteristics of respondents}

The characteristics of respondents and their companies are shown in Table 1. The results show that nearly $76 \%$ of the respondents were either vice presidents or above or managers/assistant managers. Only a few respondents held the positions of director/vice director $(5.8 \%)$, clerk $(8.5 \%)$, sales representative $(2.6 \%)$, and other positions $(7.1 \%)$. In general, managers are actively involved in and anchor operations in their businesses, and since than $75 \%$ of the responses come from managers or above this supports the reliability of the survey findings. To further assess the quality of the answers, respondents were also asked to indicate how long they had worked in the container shipping industry, and over $80 \%$ had done so for more than ten years, suggesting that they had enough practical experience to answer the questions appropriately.

The vast majority of respondents were employed by ocean freight forwarders (55.2\%), while the remainders were from liner shipping agencies $(29.2 \%)$ and liner shipping companies $(15.6 \%)$. As regards the ownership pattern, $66.2 \%$ of respondents were local firms, while $19.5 \%$ and $14.3 \%$ were foreign-owned firms and foreign-local firms, respectively. Over half (53.2\%) of responding firms had been in operation for more than 20 years. Around $55 \%$ of the responding firms had fewer than 50 employees, while $12.4 \%$ had more than 501 employees. The results also showed that $52.0 \%$ of the respondents reported that their firms' annual revenue was below NT \$100 million, whereas $37.7 \%$ had revenue between NT $\$ 101$ million and NT\$10 billion, and $10.3 \%$ reported revenue of more than this.

\section{Results of empirical analysis}

\subsection{Crucial environmental management dimensions of maritime firms}

An exploratory factor analysis with VARIMAX rotation was employed to identify the crucial environmental management dimensions in maritime firms. An eigenvalue greater than one was used to determine the number of factors in each dataset (Churchill and Iacobucci, 2002). Three factors, as shown in Table 2, were identified to underlie environmental management dimensions, and these accounted for $69.25 \%$ of the total variance. They described in more detail below:

1 Factor 1, called environmental management practices, consisted of eight items, namely: our company makes efforts to undertake environmental protection; our company executes energy conservation and recycling programs; our company complies with environmental regulations and reduces the impact of pollution on the environment; our company is devoted to developing green logistics services; our company undertakes cross-functional cooperation for environmental improvements; our company cooperates with customers for environmental projects; our company contributes to urban and community projects for environmental improvement; and our company pressures partners to take environmental action to comply with environmental regulations. The factor of environmental management practices accounted for $51.12 \%$ of the total variance in the results. 
2 Factor 2, called environmental management auditing, consisted of five items, namely: our company applies high-quality standards for disclosure, accounting, audit, environmental and CSR reporting where it is located; our company adopts high standards of environmental reporting; our company has an environmental-health-and-safety department; our company's senior managers are committed to environmental management; and our company has established environmental auditing programs. The factor of environmental management auditing accounted for $9.62 \%$ of the total variance.

3 Factor 3, called environmental management investment, consisted of three items, namely: our company spends more to purchase environmentally friendly materials; our company increases investment for environmental protection; and our company increases training costs for environmental management. The factor of environmental management investment accounted for $8.51 \%$ of the total variance.

Table 2 Factor analysis of environmental management

\begin{tabular}{|c|c|c|c|}
\hline Environmental management attributes & Factor 1 & Factor 2 & Factor 3 \\
\hline Our company makes efforts to undertake environmental protection & 0.844 & 0.160 & 0.203 \\
\hline $\begin{array}{l}\text { Our company executes energy conservation and recycling } \\
\text { programmes }\end{array}$ & 0.815 & 0.135 & -0.018 \\
\hline $\begin{array}{l}\text { Our company complies with environmental regulations and } \\
\text { reduces the impact of pollution on the environment }\end{array}$ & 0.763 & 0.307 & 0.122 \\
\hline Our company is devoted to developing green logistics services & 0.689 & 0.289 & 0.315 \\
\hline $\begin{array}{l}\text { Our company undertakes cross-functional cooperation for } \\
\text { environmental improvements }\end{array}$ & 0.619 & 0.263 & 0.318 \\
\hline $\begin{array}{l}\text { Our company cooperates with customers for environmental } \\
\text { projects }\end{array}$ & 0.575 & 0.412 & 0.325 \\
\hline $\begin{array}{l}\text { Our company contributes to urban and community projects for } \\
\text { environmental improvement }\end{array}$ & 0.561 & 0.093 & 0.481 \\
\hline $\begin{array}{l}\text { Our company pressures partners to take environmental action to } \\
\text { comply with environmental regulations }\end{array}$ & 0.547 & 0.443 & 0.326 \\
\hline $\begin{array}{l}\text { Our company applies high-quality standards for disclosure, } \\
\text { accounting, audit, environmental and CSR reporting where it is } \\
\text { located }\end{array}$ & 0.174 & 0.868 & 0.096 \\
\hline Our company adopts high standards of environmental reporting & 0.270 & 0.841 & 0.213 \\
\hline Our company has an environmental-health-and-safety department & 0.179 & 0.834 & 0.252 \\
\hline $\begin{array}{l}\text { Our company's senior managers are committed to environmental } \\
\text { management }\end{array}$ & 0.359 & 0.571 & 0.346 \\
\hline Our company has established environmental auditing programmes & 0.414 & 0.522 & 0.293 \\
\hline $\begin{array}{l}\text { Our company spends more to purchase environmentally friendly } \\
\text { materials }\end{array}$ & 0.082 & 0.254 & 0.863 \\
\hline Our company increases investment for environmental protection & 0.277 & 0.227 & 0.857 \\
\hline $\begin{array}{l}\text { Our company increases training costs for environmental } \\
\text { management }\end{array}$ & 0.244 & 0.236 & 0.802 \\
\hline Eigenvalue & 8.180 & 1.539 & 1.362 \\
\hline Percentage variance $(\%)$ & 51.12 & 9.62 & 8.51 \\
\hline
\end{tabular}




\subsection{Reliability test}

A reliability test based on Cronbach's alpha statistics and corrected item-total correlation coefficients was used to examine the consistency and reliability of the factors. The results, as shown in Table 3, indicate that the Cronbach alpha values and the corrected item-total correlation coefficients for each measure were well above the suggested threshold of 0.75 and 0.4 , respectively, and thus can be seen as reliable (Nunnally, 1978; Churchill and Iacobucci, 2002). Table 3 also shows the respondents' agreement level with each environmental management dimensions in current situation. Results indicate that maritime firms performed well with regard to environmental management practices, followed by environmental management investment and environmental management auditing.

Table 3 Results of reliability test

\begin{tabular}{lccccc}
\hline & $\begin{array}{c}\text { No. of } \\
\text { items }\end{array}$ & Mean & S.D. & Alpha & $\begin{array}{c}\text { Range of corrected } \\
\text { item-total correlation }\end{array}$ \\
\hline Environmental management practices & 8 & 3.954 & 0.207 & 0.903 & $0.610-0.779$ \\
Environmental management auditing & 5 & 3.493 & 0.251 & 0.883 & $0.601-0.836$ \\
Environmental management investment & 3 & 3.504 & 0.045 & 0.905 & $0.778-0.869$ \\
Environmental performance & 4 & 3.862 & 0.089 & 0.827 & $0.492-0.760$ \\
Financial performance & 4 & 3.523 & 0.045 & 0.845 & $0.637-0.780$ \\
Non-financial performance & 4 & 4.021 & 0.105 & 0.875 & $0.661-0.793$ \\
\hline
\end{tabular}

\subsection{Analysis of the measurement model}

Confirmatory factor analysis with a multiple-indicator measurement model was performed to assess the uni-dimensionality, reliability and validity of the construct (Anderson and Gerbing, 1988; Segars, 1997). The $\chi^{2}$ value $\left(\chi^{2}=59.180\right.$, df $=24$, $\mathrm{p}=0.000$ ) was statistically significant at the 0.05 level of significance, indicating that the differences between model-implied covariance matrix $\Sigma$ and data-observed $\mathrm{S}$ were significantly large. The initial model thus needed to be modified by examining the statistical criteria, such as standardised residuals and modification indices. An inspection of the standardised residuals was conducted and showed that none of their values exceeded 2.58 in absolute terms at the 0.05 level. However, high modification indices of approximately 4 or greater for items EP4 and environmental management auditing were found, suggesting the fit could be improved by eliminating these two items in the revised model (Hair et al., 2009). As shown in Table 4, the resulting model provided adequate fit $\left(\chi^{2}=14.350, \mathrm{df}=11, \mathrm{p}=0.214>0.05\right)$, indicating that the proposed model was purified and credible. A number of goodness-fit indices recommended by researchers were used to evaluate the measurement model (Bagozzi and Yi, 1988; Koufteros, 1999). The values of goodness-of-fit index (GFI), the comparative fit index (CFI), and the adjusted goodness-of-fit index (AGFI) all exceeded the recommended level of 0.9. Moreover, the root mean square residual (RMR) and the root-mean-square error of approximation (RMSEA) were all below the recommended level of 0.05. In summary, the various measures of overall goodness-of-fit for the model provided sufficient support for the results to be deemed an acceptable representation of the hypothesised constructs. The subsequent tests of validity, reliability, and uni-dimensionality are described below. 
Table 4 Parameter estimate, standard errors, critical ratios, and $\mathrm{R}^{2}$ for the final model ${ }^{\mathrm{a}}$

\begin{tabular}{|c|c|c|c|c|c|c|c|}
\hline \multicolumn{2}{|c|}{ Latent variable } & \multirow{2}{*}{$\begin{array}{c}\text { Factors } \\
\begin{array}{c}\text { Environmental } \\
\text { management } \\
\text { practices }\end{array}\end{array}$} & \multirow{2}{*}{$\begin{array}{c}\begin{array}{c}\text { Unstandardised } \\
\text { factor loading }\end{array} \\
0.870\end{array}$} & \multirow{2}{*}{$\begin{array}{c}\begin{array}{c}\text { Standardised } \\
\text { factor loading }\end{array} \\
0.812\end{array}$} & \multirow{2}{*}{$\begin{array}{l}\text { S.D. } \\
0.109\end{array}$} & \multirow{2}{*}{$\begin{array}{c}\text { C.R. } \\
8.005\end{array}$} & \multirow{2}{*}{$\frac{R^{2}}{0.659}$} \\
\hline$\xi 1$ & $\begin{array}{l}\text { Environmental } \\
\text { management }\end{array}$ & & & & & & \\
\hline & & $\begin{array}{c}\text { Environmental } \\
\text { management } \\
\text { investment }\end{array}$ & 1.000 & 0.719 & $--^{b}$ & --- & 0.516 \\
\hline \multirow[t]{3}{*}{$\eta 1$} & \multirow{3}{*}{$\begin{array}{l}\text { Environmental } \\
\text { performance }\end{array}$} & EP1 & 0.807 & 0.790 & 0.077 & 10.539 & 0.624 \\
\hline & & EP2 & 1.000 & 0.828 & --- & --- & 0.685 \\
\hline & & EP3 & 0.941 & 0.837 & 0.084 & 11.201 & 0.701 \\
\hline \multirow[t]{2}{*}{$\eta 2$} & \multirow{2}{*}{$\begin{array}{l}\text { Firm } \\
\text { performance }\end{array}$} & Financial & 0.706 & 0.543 & 0.138 & 5.100 & 0.294 \\
\hline & & Non-financial & 1.000 & 0.841 & --- & --- & 0.708 \\
\hline
\end{tabular}

Convergent validity can be assessed by the critical ratio (C.R.) values that are all statistically significant on the factor loadings (Dunn et al., 1994). As a rule of thumb, the C.R. needs to be greater than 1.96 or smaller than -1.96 at the 0.05 significance level if the estimate is to be acceptable (Byrne, 2001; Hair et al., 2009). The results, shown in Table 4, indicate that all the C.R. values were significant at the 0.05 level, effectively suggesting that all the indicators measure the same construct and providing satisfactory evidence of their convergent validity and uni-dimensionality (Anderson and Gerbing, 1988). Moreover, item reliability ( $\mathrm{R}^{2}$ value) can be used to estimate the reliability of a particular observed variable or item (Koufteros, 1999). With the exception of financial performance being close to the recommended level of 0.3 , all the other items easily met the 0.3 criterion, providing evidence of convergent validity (Carr and Pearson, 1999; Hair et al., 2009).

Table 5 AVE and composite reliability for each measure

\begin{tabular}{|c|c|c|c|c|c|c|}
\hline \multicolumn{2}{|c|}{ Variable } & \multirow{2}{*}{$\begin{array}{l}A V E^{\mathrm{a}} \\
0.588\end{array}$} & \multirow{2}{*}{$\begin{array}{c}\text { Construct } \\
\text { reliability }^{\mathrm{b}} \\
0.740\end{array}$} & \multirow{2}{*}{$\begin{array}{c}\xi 1 \\
\begin{array}{c}\text { Environmental } \\
\text { management }\end{array} \\
1.000\end{array}$} & \multirow{2}{*}{$\begin{array}{c}\eta 1 \\
\text { Environmental } \\
\text { performance }\end{array}$} & \multirow{2}{*}{$\begin{array}{c}\eta^{2} \\
\text { Firm } \\
\text { performance }\end{array}$} \\
\hline$\xi 1$ & $\begin{array}{l}\text { Environmental } \\
\text { management }\end{array}$ & & & & & \\
\hline$\eta 1$ & $\begin{array}{l}\text { Environmental } \\
\text { performance }\end{array}$ & 0.670 & 0.859 & $\begin{array}{c}0.616^{* *} \\
(0.379)\end{array}$ & 1.000 & \\
\hline$\eta 2$ & $\begin{array}{l}\text { Firm } \\
\text { performance }\end{array}$ & 0.501 & 0.657 & $\begin{array}{l}0.507 * * \\
(0.257)\end{array}$ & $\begin{array}{c}0.475 * * \\
(0.226)\end{array}$ & 1.000 \\
\hline
\end{tabular}

Notes: ${ }^{\text {a AVE }}=$ (sum of squared standardised loading $) /[$ (sum of squared standardised loadings $)+($ sum of indicator measurement error)]; indicator measurement error can be calculated as $1-(\text { standardised loading })^{2}$

${ }^{\mathrm{b}}$ Construct reliability $=(\text { sum of standardised loading })^{2} /[($ sum of standardised loading $)^{2}+($ sum of indicator measurement error $\left.)\right]$; indicator measurement error can be calculated as $1-(\text { standardised loading })^{2}$

$* * p<0.01$. 
Discriminant validity was assessed by comparing the average variance extracted (AVE) with the squared correlation between constructs (Fornell and Larcker, 1981; Koufteros, 1999). As can be seen in Table 5, the highest squared correlation was observed between environmental management and environmental performance, and it was 0.379 . This was significantly lower than their individual AVEs, which were 0.588 and 0.670 , respectively. Accordingly, the results demonstrate the discriminant validity of the study constructs.

Construct reliability provides a measure of the internal consistency and homogeneity of the items comprising a scale (Churchill, 1979). The reliability is the degree to which a set of two or more indicators share the measurement of a construct. Highly reliable constructs are those in which the indicators are highly inter-correlated, indicating that are all measuring the same latent construct. The range of values for reliability is between 0 and 1. The results in Table 5 indicate that the reliability of the constructs of environmental management, environmental performance, and firm performance scales was $0.740,0.859$, and 0.657 , respectively, all of which exceeded the recommended level of 0.60 (Bagozzi and Yi, 1988; Sanchez-Rodriguez et al., 2005; Hair et al., 2009).

In addition, a complementary measure to construct reliability is the average variance extracted, which directly shows the amount of variance that is captured by the construct in relation to the amount of variance due to the measurement error. Higher variance extracted values occur when the indicators are truly representative of the latent construct. Typically, recommendations suggest that the variance extracted value should exceed 0.50 for a construct (Fornell and Larcker, 1981; Bagozzi and Yi, 1988; Hair et al., 2009). Table 5 shows that among the AVEs of the measures, firm performance had the lowest value of 0.501 , indicating that $50.1 \%$ of the variance in the specified indicators was accounted for by this construct, and the average variance extracted value of each construct in our model was higher than the recommended level of 50\% (Fornell and Larcker, 1981). To summarise, the overall results of the goodness-of-fit and the assessment of the measurement model lend substantial support to the proposed model.

Table 6 Results of the structural equation modelling

\begin{tabular}{lcccccc}
\hline Relationships & Estimate & S.E. & C.R. & $P$ & Sign & Supported \\
\hline $\begin{array}{l}\text { Environmental management } \rightarrow \\
\text { environmental performance }\end{array}$ & $0.964^{\mathrm{c}}$ & 0.139 & 6.910 & 0.000 & + & Supported \\
$\begin{array}{l}\text { Environmental management } \rightarrow \\
\text { firm performance }\end{array}$ & 0.507 & 0.166 & 3.060 & 0.002 & + & Supported \\
$\begin{array}{l}\text { Environmental performance } \rightarrow \\
\text { firm performance }\end{array}$ & 0.133 & 0.123 & 1.088 & 0.277 & + & Not supported \\
\hline
\end{tabular}

Notes: ${ }^{\text {a }}$ S.E. is an estimate of the standard error of the covariance.

${ }^{\mathrm{b}} \mathrm{C} . \mathrm{R}$. is the critical ratio obtained by dividing the covariance estimate by its standard error.

${ }^{\mathrm{c}}$ Italic values are critical ratios exceeding 1.96 at the 0.05 level of significance.

Fit indices: $\chi^{2}=14.350(\mathrm{p}=0.214), \mathrm{df}=11, \chi^{2} / \mathrm{df}=1.305, \mathrm{GFI}=0.975$, AGFI $=0.936, \mathrm{CFI}=0.992, \mathrm{RMR}=0.013, \mathrm{RMSEA}=0.045$.

\subsection{SEM: hypotheses testing}

After confirming the fitness of the proposed model, this study then examined the hypothesised relationships. As can be seen from Table 6, environmental management was found to have significant influences on environmental performance (estimate $=0.964$, 
C.R. > 1.96) and firm performance (estimate $=0.507$, C.R. $>1.96$ ). However, there was no support for a significant positive relationship between environmental performance (estimate $=0.133$, C.R. $<1.96$ ) and firm performance. The results indicated that maritime firms which make efforts to undertake environmental management activities can enhance both environmental performance and firm performance. The above findings are consistent with those in Zhu and Sarkis (2004), Claver et al. (2007) and López-Gamero et al. (2009).

\section{Conclusions and discussions}

This study developed a model to examine the impact of environmental management on environmental performance and firm performance, and the main findings are summarised below.

Factor analysis was employed to identify the critical environmental management dimensions, three of which were identified, namely, environmental management practices, environmental management auditing, and environmental management investment. The findings indicated that maritime firms perform well with regard to environmental management practices, followed by environmental management investment and environmental management auditing. Thus, maritime firms need to make efforts in environmental management investment and auditing.

SEM was employed to evaluate the relationships among environmental management, environmental performance, and firm performance. A significantly positive relationship was found between environmental management and environmental performance $\left(\mathrm{H}_{1}\right)$, which implies that maritime firms which mane efforts in environmental management can significantly improve their environmental performance. Therefore, investment in environmental management and initiation of environmental management practices, such as environmental protection, energy conservation and recycling programs, cross-functional cooperation, cooperation with customers and obeying environmental regulations, can all significantly improve environmental performance. The finding is consistent with previous studies (Zhu and Sarkis, 2004; Claver et al., 2007; Darnall et al., 2008; Lee, 2008).

The results also indicate a significantly positive relationship between environmental management and firm performance $\left(\mathrm{H}_{2}\right)$. Although some researchers argued that the implementation of environmental management activities could impose additional costs on firms (Walley and Whitehead, 1994; Horváthová, 2010), this study found that they can lead to win-win situations in which both social welfare as well as the private benefits of firms increase (Porter, 1991). Accordingly, this finding implies that environmental management could help maritime firms to improve their firm performance, which is consistent with some previous studies (Montabon et al., 2007; López-Gamero et al., 2009).

However, the effect of environmental performance on firm performance $\left(\mathrm{H}_{3}\right)$ was not supported in this study, which implies that better environmental performance does not necessarily lead to superior firm performance. This is consistent with Wagner (2001), which argued that there is only a moderate positive relationship between environmental performance and firm performance, or that no systematic relationship exists.

One of the major contributions of this study is that it is the first attempt to examine the impacts of environmental management on environmental performance and firm 
performance in the context of maritime firms. Moreover, this study contributes to the literature by demonstrating that the implementation of environmental management can lead to improved environmental performance and firm performance. Finally, this study indicates that increased investment in environmental protection, training, and environmentally friendly materials can lead to superior environmental performance and firm performance.

From a theoretical perspective, this study contributes to the field by identifying environmental management dimensions and examining their effects on environmental performance and firm performance. However, it suffers from several limitations. First, different sized maritime firms may have different resources for implementing environmental management systems, and thus future research could identify the drivers and barriers to adopting such practices. Another worthwhile direction for future research might be using the strategic group concept to classify maritime firms into different environmentally management-oriented firms based on the aforementioned environmental management dimensions. Finally, the data used in this study was collected at one point in time, and therefore the hypothesised relationships were examined in a static fashion. In future work, longitudinal research could be employed to indicate how perceptions of key resources and logistics service capabilities change over time.

\section{Acknowledgements}

This research was sponsored by the National Science Council in Taiwan under Grant Number NSC 98-2410-H-022-006.

\section{References}

Anderson, J. and Gerbing, D.W. (1988) 'Structural equation modeling in practice: a review and recommended two-step approach', Psychological Bulletin, Vol. 103, No. 2, pp.411-423.

Armstrong, S.J. and Overton, T.S. (1977) 'Estimating nonresponse bias in mail survey', Journal of Marketing Research, Vol. 14, No. 6, pp.396-402.

Bagozzi, R.P. and Yi, Y. (1988) 'On the evaluation of structural equation models', Academy of Marketing Science, Vol. 6, No. 1, pp.74-93.

Byrne, B.M. (2001) Structural Equation Modeling with AMOS: Basic Concepts, Applications, and Programming, Lawrence Erlbaum Associates, New Jersey.

Carr, A.S. and Pearson, J.N. (1999) 'Strategically managed buyer-supplier relationships and performance outcomes', Journal of Operations Management, Vol. 17, No. 5, pp.497-519.

Churchill, G.A. (1979) 'A paradigm for developing better measures of marketing constructs', Journal of Marketing Research, Vol. 16, No. 1, pp.360-375.

Churchill, G.A. and Iacobucci, D. (2002) Marketing Research: Methodological Foundation, 8th ed., South-Western, USA.

Claver, E., López, M.D., Molina, J.F. and Tarí, J.J. (2007) 'Environmental management and firm performance: a case study', Journal of Environmental Management, Vol. 84, No. 4, pp.606-619.

Darnall, N., Henriques, I. and Sadorsky, P. (2008) 'Do environmental management systems improve business performance in an international setting?', Journal of International Management, Vol. 14, No. 4, pp.364-376. 
Dess, G.G. and Robinson, J. (1984) 'Measuring organizational performance in the absence of objective measures: the case of the privately-held firm and conglomerate business unit', Strategic Management Journal, Vol. 5, No. 3, pp.265-273.

Dunn, S.C., Seaker, R.F. and Waller, M.A. (1994) 'Latent variables in business logistics research: scale development and validation', Journal of Business Logistics, Vol. 15, No. 2, pp.145-172.

Fornell, C. and Larcker, D.F. (1981) 'Evaluating structural equation models with unobservable and measurement error', Journal of Marketing Research, Vol. 30, No. 2, pp.65-73.

Giziakis, C. and Christodoulou, A. (2010) 'Environmental awareness and practice concerning maritime air emissions: the case of the Greek shipping industry', Proceedings of the IAME 2010 Annual Conference, CD files, Lisbon, Portugal.

Hair, J.F., Black, B., Babin, B., Anderson, R.E. and Tatham, R.L. (2009) Multivariate Data Analysis, 6th ed., Pearson Education Taiwan Ltd., Taiwan.

Horváthová, E. (2010) 'Does environmental performance affect financial performance? A meta-analysis', Ecological Economics, Vol. 70, No. 1, pp.52-59.

International Energy Agency (IEA) (2010) 'Co2 emissions from fuel combustion-2010 highlights', available at http://www.energyconf.ir/pdf/7.pdf (accessed on 20 February 2011).

Jasch, C. (2000) 'Environmental performance evaluation and indicators', Journal of Cleaner Production, Vol. 8, No. 1, pp.79-88.

Kaplan, R.S. and Norton, D.P. (1992) 'The balanced scorecard - measures that drive performance', Harvard Business Review, Vol. 70, No. 1, pp.71-79.

Koufteros, X.A. (1999) 'Testing a model of pull production: a paradigm for manufacturing research using structural equation modeling', Journal of Operations Management, Vol. 17, No. 4, pp.467-488.

Labonne, J. (2006) 'A comparative analysis of the environmental management, performance and innovation of SEMs and larger firms', available at http://ec.europa.eu/environment/sme/ pdf/final_report_sme_en.pdf (accessed on 20 February 2011).

Lee, C.W. (2008) 'Green suppliers with environmental performance in the supply chain perspective', Asia Pacific Management Review, Vol. 13, No. 4, pp.731-745.

Liao, C.H., Tseng, P.H., Cullinane, K. and Lu, C.S. (2010) 'The impact of an emerging port on the carbon dioxide emissions of island container transport: an empirical study of Taipei port', Energy Policy, Vol. 38, No. 9, pp.5251-5257.

Liu, X., Liu, B., Shishime, T., Yu, Q., Bi, J. and Fujitsuka, T. (2010) 'An empirical study on the driving mechanism of proactive corporate environmental management in China', Journal of Environmental Management, Vol. 91, No. 8, pp.1707-1717.

López-Gamero, M.D., Molina-Azoŕin, J.F. and Claver-Cortés, E. (2009) 'The whole relationship between environmental variables and firm performance: competitive advantage and firm resources as mediator variables', Journal of Environmental Management, Vol. 90, No. 10 , pp.3110-3121.

Lu, C.S., Lin, C.C. and Tu, C.J. (2009) 'Corporate social responsibility and organizational performance in container shipping', International Journal of Logistics: Research and Applications, Vol. 12, No. 2, pp.119-132.

Lun, Y.H.V. and Marlow, P. (2011) 'The impact of capacity on firm performance: a study of the liner shipping industry', International Journal of Shipping and Transport Logistics, Vol. 3, No. 1, pp.57-71.

Lun, Y.H.V., Pang, K.W. and Panayides, P.M. (2010) 'Organisational growth and firm performance in the international container shipping industry', International Journal of Shipping and Transport Logistics, Vol. 2, No. 2, pp.206-223.

Ministry of Transportation and Communication (2010) 'Transportation research statistics', available at $\mathrm{http} / / \mathrm{www} . m o t c . g o v . t w$ (accessed on 20 February 2011).

Mishra, S. and Suar, D. (2010) 'Does corporate social responsibility influence firm performance of Indian companies?', Journal of Business Ethics, Vol. 95, No. 4, pp.571-601. 
Montabon, F., Sroufe, R. and Narasimhan, R. (2007) 'An examination of corporate reporting, environmental management practices and firm performance', Journal of Operations Management, Vol. 25, No. 5, pp.998-1014.

Murphy, P.R., Poist, R.F. and Braunschhwieg, C.D. (1994) 'Management of environmental issues in logistics: current status and future potential', Transportation Journal, Vol. 34, No. 1, pp.48-56.

Nunnally, J.C. (1978) Psychometric Theory, 2nd ed., McGraw-Hill, New York.

Panayides, P.M. and Polyviou, M. (2011) 'The effect of ports' logistics attributes and services on the business and supply chain performance of shipping firms', International Journal of Shipping and Transport Logistics, Vol. 3, No. 4, pp.430-453.

Porter, M.E. (1991) 'America's green strategy', Scientific American, Vol. 264, No. 4, p.96.

Sanchez-Rodriguez, C., Hemsworth, D. and Martinez-Lorente, A.R. (2005) 'The effect of supplier development initiatives on purchasing performance: a structural model', Supply Chain Management: An International Journal, Vol. 10, No. 4, pp.289-301.

Segars, A. (1997) 'Assessing the unidimensionality of measurement: a paradigm and illustration within the context of information systems research', Omega - International Journal of Management Science, Vol. 25, No. 1, pp.107-121.

Shang, K.C., Lu, C.S. and Li, S. (2010) 'A taxonomy of green supply chain management capability among electronics-related manufacturing firms in Taiwan', Journal of Environmental Management, Vol. 91, No. 5, pp.1218-1226.

Venkatraman, N. and Ramanujam, V. (1986) 'Measurement of business performance in strategy research: a comparison of approaches', Academy of Management Review, Vol. 11, No. 4, pp.801-814.

Wagner, M. (2001) 'A review of empirical studies concerning the relationship between environmental and financial performance: what does the evidence tell us?', Center for Sustainability Management e.V., available at http://www.sussex.ac.uk/Units/spru/mepi/ outputs/Wagner.PDF (accessed on 20 February 2011).

Wagner, M. and Schaltegger, S. (2004) 'The effect of corporate environmental strategy choice and environmental performance on competitiveness and economic performance: an empirical study of EU manufacturing', European Management Journal, Vol. 22, No. 5, pp.557-572.

Walley, N. and Whitehead, B. (1994) 'It's not easy being green', Harvard Business Review, Vol. 76, No. 3, pp.46-51.

Yang, C.L., Lin, S.P., Chan, Y.H. and Sheu, C. (2010) 'Mediated effect of environmental management on manufacturing competitiveness: an empirical study', International Journal of Production Economics, Vol. 123, No. 1, pp.210-220.

Zervas, E. (2006) ' $\mathrm{CO}_{2}$ benefit from the increasing percentage of diesel passenger cars: case of Ireland', Energy Policy, Vol. 34, No. 17, pp.2848-2857.

Zhang, X., Shen, L. and Wu, Y. (2011) 'Green strategy for gaining competitive advantage in housing development: a China study', Journal of Cleaner Production, Vol. 19, Nos. 2-3, pp.157-167.

Zhu, Q. and Sarkis, J. (2004) 'Relationships between operational practices and performance among early adopters of green supply chain management practices in Chinese manufacturing enterprises', Journal of Operations Management, Vol. 22, No. 3, pp.265-289.

Zhu, Q., Sarkis, J., Cordeiro, J.J. and Lai, K.H. (2008) 'Firm-level correlates of emergent green supply chain management practices in the Chinese context', The International Journal of Management Science, Vol. 36, No. 4, pp.577-591. 